20. Uslu R, Jewett A, Bonavida B. Sensitization of human ovarian tumor cells by subtoxic CDDP to anti-fas antibody-mediated cytotoxicity and apoptosis. Gynecol Oncol. 1996;62:282-91.

21. Kinoshita H, Yoshikawa H, Shiiki K, Hamada Y, Nakajima Y, Tasaka K. Cisplatin (CDDP) sensitizes human osteosarcoma cell to Fas/CD95-mediated apoptosis by down-regulating FLIP-L expression. Int J Cancer. 2000;88:986-91.

22. Kuwahara D, Tsutsumi K, Kobayashi T, Hasunuma T, Nishioka K. Caspase-9 regulates cisplatin-induced apoptosis in human head and neck squamous cell carcinoma cells. Cancer Lett. 2000;148:65-71.

23. Miyajima A, Nakashima J, Tachibana M, Nakamura K, Hayakawa M, Murai M. $\mathrm{N}$-acetylcysteine modifies cis-dichlorodiammineplatinuminduced effects in bladder cancer cells. Jpn J Cancer Res. 1999;90:565-70.

24. Simon MM, Waring P, Lobigs M, Nil A, Tran T, Hla RT, et al. Cytotoxic T cells specifically induce Fas on target cells, thereby facilitating exocytosis-independent induction of apoptosis. J Immunol. 2000;165:3663-72.
25. Owen-Schaub LB, Angelo LS, Radinsky R, Ware CF, Gesner TG, Bartos DP. Soluble Fas/APO-1 in tumor cells: a potential regulator of apoptosis? Cancer Lett. 1995;94:1-8.

26. Bossi G, Stinchcombe JC, Page LJ, Griffiths GM. Sorting out the multiple roles of Fas ligand. Eur J Cell Biol. 2000;79:539-43.

\section{Discussion}

Dr Ralph A. Schmid (Berne, Switzerland). Did you look at liver function in the animal studies? When you give FasL systemically, animals die of liver failure.

Dr Stewart. Actually, those studies came from intraperitoneal injection of Jo2 agonistic antibodies to Fas, and there was massive hepatic necrosis in those previous studies. However, with our intraperitoneal injections of Fas, we saw no changes in liver morphology, as evidenced by hematoxylin and eosin staining.

\title{
JTCVS On-Line Manuscript Submission and Review
}

\section{Please visit http://www.editorialmanager.com/jtcvs/}

Effective September 15, 2001, authors and reviewers may submit manuscripts and reviews electronically via Editorial Manager, our new Web-based system with full electronic submission, review, and status update capabilities.

As we move from paper to electronic submissions, the Editorial Office will make proxy submissions of all manuscripts accompanied by a diskette containing the electronic files of the text, tables, and figures. Editors, authors, and reviewers will receive automatic e-mails when significant events occur.

We strongly encourage all authors and reviewers to use Editorial Manager. Although we will continue to accommodate the submission of paper manuscripts for some months, our goal is to be completely electronic within 9 to 12 months.

All individuals currently in our database for whom we have e-mail addresses will receive via e-mail a system-assigned username and password that can be used to log in to the system without prior registration. All those not receiving the e-mail must register the first time they use the system.

As with any broad systemic change, the conversion to the new system will take some time to complete. We ask your patience as we replace our in-office database with the new system. We also encourage you to take advantage of the speed and efficiency that the new system will provide for us all: editor, author, reviewer, and publisher. 